\title{
Hydrogen-Bonded Xanthones as Potential UV Absorbers: The Synthesis of Xanthones from Bio-Renewable Cardanol Utilizing a Ceric Ammonium Sulfate (CAS)-Mediated Oxidation Reaction
}

\author{
Fatema Jagot \\ Izak Minnie \\ Aliyaah Rahman' \\ Songeziwe Ntsimango \\ Kennedy J. Ngwira \\ Charles B. de Koning*(C) \\ Molecular Sciences Institute, School of Chemistry, University of \\ the Witwatersrand, PO Wits 2050, South Africa \\ Charles.deKoning@wits.ac.za
}

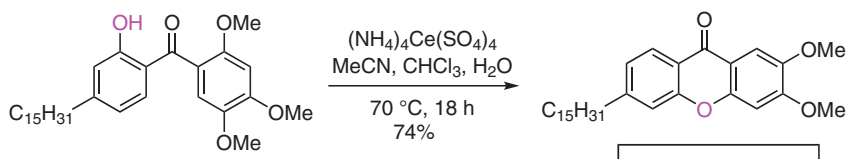

$\mathrm{Ru}\left[(\text { p-cymene }) \mathrm{Cl}_{2}\right]_{2}$ $\mathrm{K}_{2} \mathrm{~S}_{2} \mathrm{O}_{8}$, TFA/TFAA (1:0.05)

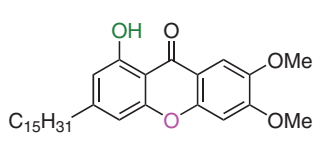

UVB $(290 \mathrm{~nm})$ ع $20320\left(\mathrm{~cm}^{-1} \mathrm{M}^{-1}\right)$ UVA $(368 \mathrm{~nm})$ $13949\left(\mathrm{~cm}^{-1} \mathrm{M}^{-1}\right)$

\begin{abstract}
Received: 11.01 .2022
Accepted after revision: 28.01.2022

Published online: 24.02 .2022

DOI: 10.1055/s-0040-1719903; Art ID: so-2022-d0001-op

License terms: CCO

(c) 2022. The Author(s). This is an open access article published by Thieme under the terms of the Creative Commons Attribution-NonDerivative-NonCommercial-License, permitting copying and reproduction so long as the original work is given appropriate credit. Contents may not be used for commercial purposes or adapted, remixed, transformed or built upon. (https://creativecommons.org/licenses/by-nc-nd/4.0/)
\end{abstract}

Abstract The synthesis of hydrogen-bonded xanthones by using biorenewable hydrogenated cardanol (3-pentadecylphenol) is described. Hydrogenated cardanol was initially converted into various hydroxybenzophenones. These benzophenones were converted into xanthones by utilizing an oxidative ceric ammonium sulfate-mediated reaction. A subsequent ruthenium-mediated late-stage oxidation of the xanthones provided hydrogen-bonded xanthones, which displayed good UVA and UVB absorbing properties.

Key words cardanols, benzophenones, ceric ammonium sulfate, oxidative addition, xanthones, UV absorbers

Xanthones $^{2-4}$ belong to a class of compounds that display extensive biological activities, including significant antitumor, ${ }^{5}$ antioxidant, ${ }^{3}$ antimalarial, ${ }^{6}$ antiinflammatory, ${ }^{7}$ and anti-HIV activity. ${ }^{8} \mathrm{~A}$ few examples are shown in Figure 1. These include bikaverin (1), sporospermin (2), mangiferin (3), dombakinaxanthone (4), macluraxanthone (5), and the antiinflammatory xanthone $\mathbf{6}$. As a result, many synthetic approaches towards the assembly of the xanthone core have been developed. ${ }^{3,9}$

We have recently reported on a new method for the synthesis of xanthones and related compounds. ${ }^{10}$ This involved the treatment of phenol-containing benzophenones with ceric ammonium sulfate (CAS) that allowed for an oxidative cyclization to form xanthones and related products. ${ }^{11}$

In addition, our group has demonstrated the use of biorenewable resources for the synthesis of new UV absorb-

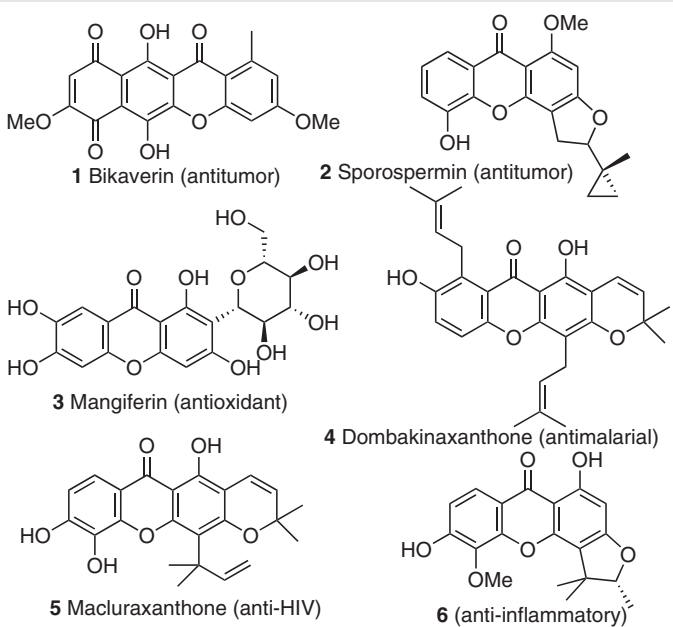

Figure 1 Examples of biologically active xanthones

ers. ${ }^{12}$ Utilizing anacardic acids and cardanols extracted from cashew nut shells, we were able to synthesize a range of hydrogen-bonded aromatic and heteroaromatic compounds, and their UV spectra were obtained. We found that two cardanol-derived triazines $\mathbf{7}$ and $\mathbf{8}$ (Figure 2) showed excellent characteristics to be potential UV absorbers. ${ }^{12}$ Notably, triazine 8 showed absorbance in both the UVA and UVB regions with experimental $\varepsilon$ values of $21,452 \mathrm{~L} \mathrm{~mol}^{-1}$ $\mathrm{cm}^{-1}$ at $300 \mathrm{~nm}$ and $12,515 \mathrm{~L} \mathrm{~mol}^{-1} \mathrm{~cm}^{-1}$ at $364 \mathrm{~nm}$. These results indicate that triazine 8 could be classified as a broad-spectrum UV filtering agent.

In this paper, we report on the use of our recently reported ${ }^{11}$ ceric ammonium sulfate (CAS)-mediated oxidative cyclization reaction ${ }^{13}$ to synthesize several hydrogen-bonded xanthones from benzophenones intermediates. The benzophenones were synthesized, in part, from the bio- 


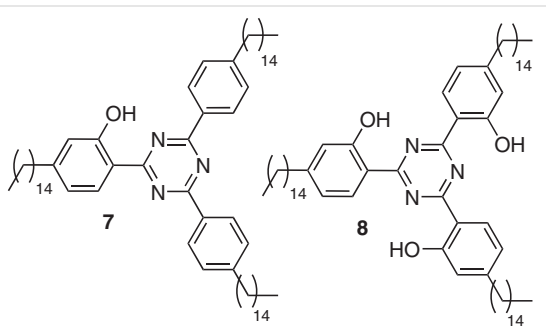

Figure 2 Hydrogen-bonded triazines synthesized from bio-renewable cardanol

renewable starting material hydrogenated cardanol (3-pentadecylphenol). We also report on the UV absorption properties of the synthesized hydrogen-bonded xanthones.

As a starting point for the construction of the desired xanthones, we chose to attempt the assembly of the hydrogen-bonded benzophenone $\mathbf{9}$ by means of the addition of the aromatic Grignard reagent derived from $\mathbf{1 0}$ to benzaldehyde 11a. In turn, we anticipated that benzaldehyde 11a could be obtained from hydrogenated cardanol (12). Indeed, by utilizing standard formylation conditions, or a greener $\mathrm{MgBr}_{2}$-mediated protocol, hydrogenated cardanol was converted into benzaldehyde 11a (Scheme 1). Reaction of 11a with the Grignard reagent derived from 1-bromo2,5-dimethoxybenzene (10) resulted in the formation of the secondary alcohol 13a. The alcohol 13a was then oxidized to the required benzophenone $\mathbf{9}$, by utilizing $\mathrm{MnO}_{2}$ or by an alternative solvent-free method using $\mathrm{CuSO}_{4} / \mathrm{KMnO}_{4}$. As our first CAS-mediated test example, benzophenone $\mathbf{9}$ was exposed to ceric ammonium sulfate to afford the desired xanthone 14 in a good yield of 70\%. In this case, slightly modified reaction conditions for the CAS reaction were employed, in that the reaction mixture was heated to $70{ }^{\circ} \mathrm{C}$ instead of conducting the reaction at room temperature. ${ }^{11}$ On repeating the Grignard reaction, we found that the reac- tion did not provide reproducible yields. This might be a result of the phenol on benzaldehyde $\mathbf{1 1}$ interfering with the reaction. Therefore, an alternative method for the synthesis of the benzophenone $\mathbf{9}$ had to be sought. Furthermore, our attempts at forming other derivatives of the secondary alcohol were unsuccessful. For example, the attempted synthesis of 13b from benzaldehyde $\mathbf{1 1 b}$ and $\mathbf{1 0}$ through a Grignard reaction met with failure.

Reacting hydrogenated cardanol (12) with three different benzoic acids in the presence of TFAA in the nonchlorinated solvent toluene provided the three esters 15-17 in good yields, as shown in Scheme 2 . The same reaction could also be conducted in dichloromethane, as described in the experimental section. The conversion of the esters $\mathbf{1 5}, \mathbf{1 6}$, and 17 by means of a Fries rearrangement to furnish the desired hydroxybenzophenones 9,18 , and 19 proved to be problematic.
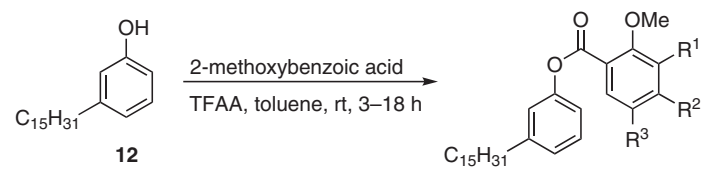

15, $\mathrm{R}^{1}=\mathrm{H}, \mathrm{R}^{2}=\mathrm{H}, \mathrm{R}^{3}=\mathrm{OMe}, 95 \%$ 16, $R^{1}=\mathrm{OMe}, \mathrm{R}^{2}=\mathrm{H}, \mathrm{R}^{3}=\mathrm{H}, 83 \%$ $17, \mathrm{R}^{1}=\mathrm{H}, \mathrm{R}^{2}=\mathrm{OMe}, \mathrm{R}^{3}=\mathrm{OMe}, 78 \%$

Scheme 2 Synthesis of aromatic esters as precursors for the Fries rearrangement

Experimenting with a number of conditions, such as heating with Lewis acids (e.g., $\mathrm{AlCl}_{3}$ ), led only to decomposition. Photochemical Fries conditions disappointingly resulted in mixtures of the ortho and para products produced in low yields, while anionic Fries rearrangement conditions met with no success. The best yields for the Fries rearrangement were obtained by utilizing slightly different reaction conditions for each substrate. For example, ester 15 was
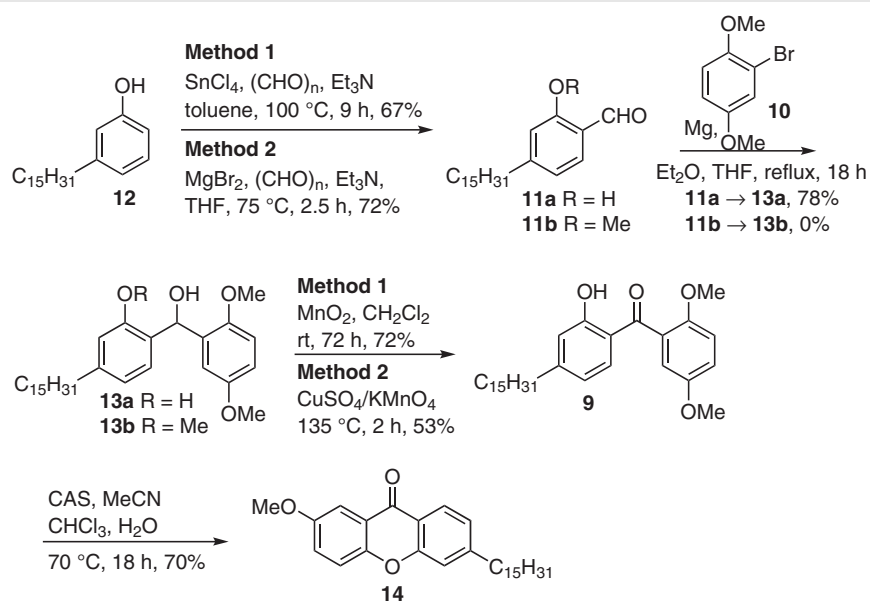

Scheme 1 Initial attempts at the synthesis of xanthones from benzophenones utilizing a ceric ammonium sulfate-mediated oxidative cyclization reaction 
converted into benzophenone $\mathbf{9}$ in the presence of methanesulfonic acid and phosphorus pentoxide (Eaton's reagent ${ }^{14}$ ) in a reproducible yield of $50 \%$, with the recovery of some starting material 15 (20\%) (Scheme 3 ). In addition, dimethoxy aromatic ester $\mathbf{1 6}$ was transformed into 18 in the presence of the related stronger acid, trifluoromethanesulfonic acid in a good yield of 63\%. However, the trimethoxybenzene $\mathbf{1 7}$ only afforded the desired benzophenone $\mathbf{1 9}$ in a poor yield of $20 \%$.

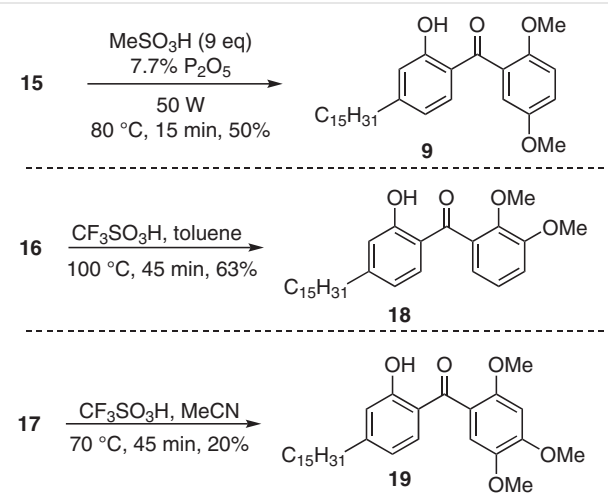

Scheme 3 Fries rearrangements for the synthesis of benzophenones

The stage was now set to conduct the oxidative-mediated CAS reaction (Scheme 4). As before benzophenone 9 yielded xanthone 14 in good yield. Benzophenone 18 furnished xanthone 20, and benzophenone 19 afforded xanthone 21, both in good yields. The final step of the synthesis involved the carbonyl-directed late-stage alcohol functionalization of the three xanthones 14, 20, and 21 with a ruthenium catalyst in the presence of [bis(trifluoroacetoxy)iodo]benzene (PIFA) or $\mathrm{K}_{2} \mathrm{~S}_{2} \mathrm{O}_{8}$, as an oxidant, and TFAA/TFA. ${ }^{15}$ Reaction with each of the xanthones 14, 20, and $\mathbf{2 1}$ afforded the desired hydrogen-bonded xanthones 22-24, albeit in poor yields. The reaction is believed to commence with a carboxylate-assisted $\mathrm{C}-\mathrm{H}$ ruthenation, where the ketone of the xanthone allows for ruthenium coordination. This is followed by an oxidation-induced reductive elimination to introduce the alcohol. ${ }^{15 c}$ Interestingly, xanthones 14 and 21 exhibited similar regioselectivities, where the $\mathrm{OH}$ functionalization took place on the cardanolderived half of the molecule, giving xanthones 22 and 24 respectively, whereas xanthone $\mathbf{2 0}$ was hydroxylated on the anisole fragment, forming xanthone 23.

These hydroxyxanthones, together with the hydroxybenzophenones, exhibit hydrogen bonding, and are therefore potential UV absorbers. ${ }^{16}$

UVA and UVB rays occur at wavelengths of 315-400 and 280-315 nm respectively. Materials and human or animal skin need to be protected from these harmful rays. The six hydrogen-bonded aromatic compounds 9, 18, 19, 22-24 that we had synthesized were examined as possible UV absorbers. The three benzophenones $\mathbf{9}, \mathbf{1 8}$, and 19 showed

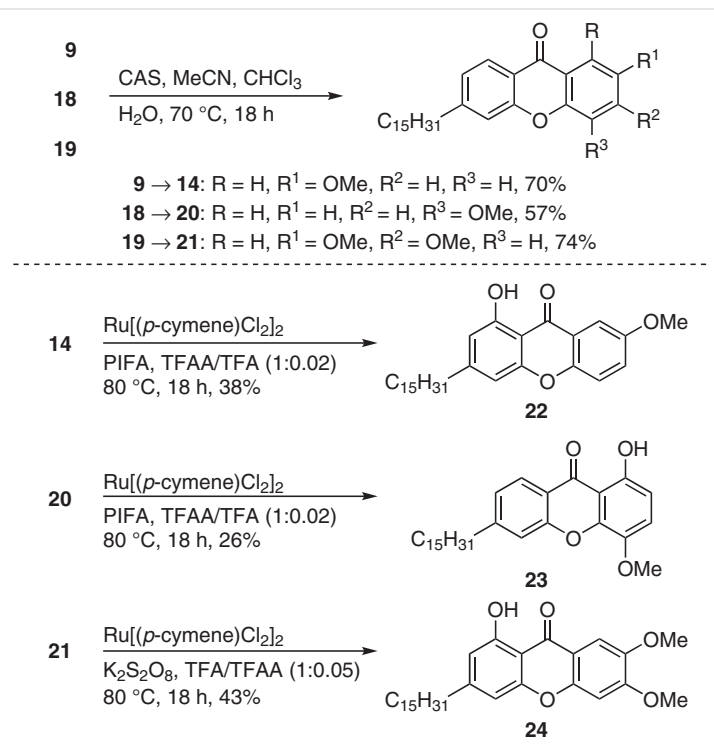

Scheme 4 CAS-mediated oxidative cyclization reactions of benzophenones, followed by late-stage ruthenium-mediated hydroxylation

$\lambda_{\text {max }}(\mathrm{nm})$ values in the UVA range (Table 1$)$, while two of the hydrogen-bonded xanthones, compounds 22 and 24, showed $\lambda_{\max }(\mathrm{nm})$ values in both the UVA and UVB ranges (Table 1 and Figure 3).

Table 1 UV Spectral Data for Hydrogen-Bonded Compounds 9, 18, $19,22,23$, and 24

\begin{tabular}{lcl}
\hline Compound & $\lambda_{\max }(\mathrm{nm})$ & $\varepsilon\left(\mathrm{cm}^{-1} \mathrm{M}^{-1}\right)$ \\
\hline $\mathbf{9}$ & 239 & 14997.44 \\
& 273 & 24839.51 \\
$\mathbf{1 8}$ & 338 & 9045.33 \\
& 239 & 19777.87 \\
$\mathbf{1 9}$ & 274 & 30041.75 \\
& 334 & 10310.74 \\
$\mathbf{2 2}$ & 240 & 22241.57 \\
& 273 & 31417.47 \\
& 345 & 13015.81 \\
$\mathbf{2 3}$ & 240 & 22133.61 \\
& 265 & 41913.54 \\
& 290 & 12628.38 \\
$\mathbf{2 4}$ & 384 & 6653.66 \\
& 240 & 22405.19 \\
& 271 & 28470.43 \\
& 348 & 2896.83 \\
& 384 & 4118.93 \\
\hline
\end{tabular}

Of particular interest, xanthone $\mathbf{2 4}$ showed a molar absorption coefficient of $20320 \mathrm{~L} \mathrm{~mol}^{-1} \mathrm{~cm}^{-1}$ in the UVB range $(290 \mathrm{~nm})$ and a molar absorption coefficient of $13949 \mathrm{~L}$ $\mathrm{mol}^{-1} \mathrm{~cm}^{-1}(368 \mathrm{~nm})$ in the UVA range, indicating that xanthone $\mathbf{2 4}$ could be potentially useful for the protection of 

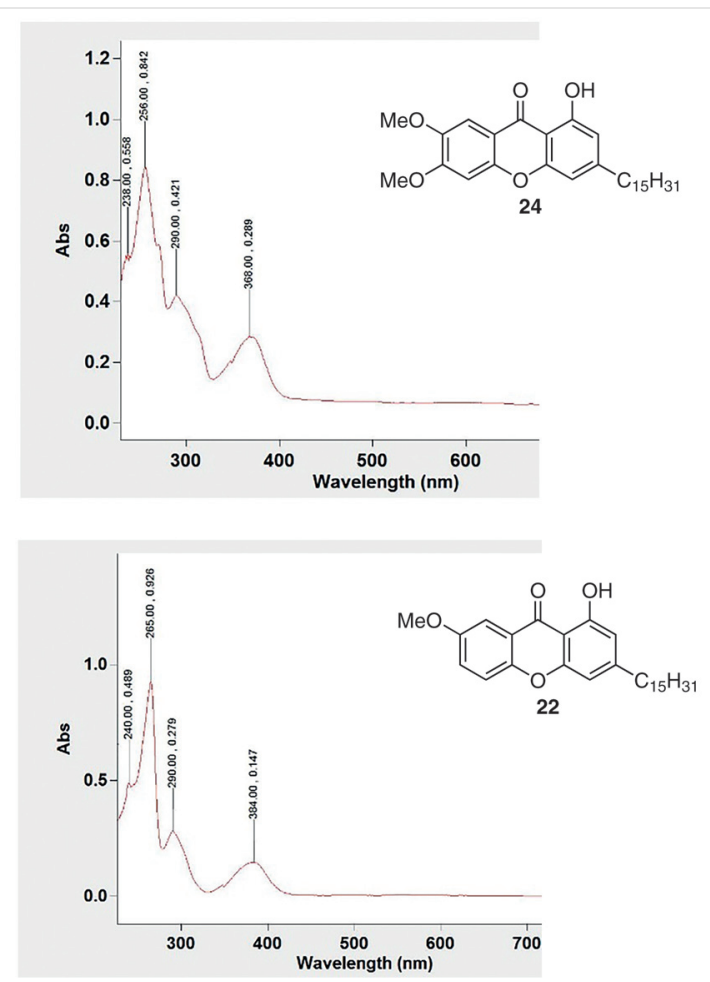

Figure 3 UV spectra of hydrogen-bonded xanthones 22 and 24

materials or as a sunscreen. In comparison, the commercially available sunscreen agents oxybenzone (OB), 2-ethylhexyl 4-methoxycinnamate (OMC), and avobenzone are reported to show experimental molar absorption coefficients of $15150 \mathrm{~L} \mathrm{~mol}^{-1} \mathrm{~cm}^{-1}$ at $287 \mathrm{~nm}, 39470 \mathrm{~L} \mathrm{~mol}^{-1} \mathrm{~cm}^{-1}$ at 356 $\mathrm{nm}$, and $31670 \mathrm{~L} \mathrm{~mol}^{-1} \mathrm{~cm}^{-1}$ at $310 \mathrm{~nm}$, respectively. ${ }^{17}$

In summary, we have been able to demonstrate that utilizing the bio-renewable starting material hydrogenated cardanol allows for the assembly of xanthones through an oxidative ceric ammonium sulfate (CAS)-mediated methodology. The products were converted into hydrogen-bonded xanthones. One of the xanthones 24 synthesized showed promising UVA and UVB activities.

The solvents and reagents used for this project were purchased from ACE Chemicals or Sigma-Aldrich, and were used without purification unless otherwise stated. Acetonitrile (MeCN) was distilled over calcium hydride under nitrogen gas. Tetrahydrofuran (THF) was distilled over sodium wire and benzophenone under nitrogen gas. Thin-layer chromatography (TLC) was performed on aluminum-backed ALUGRAM Sil G/UV 254 plates that were precoated with $0.25 \mathrm{~mm}$ silica gel 60 . The compounds were detected by using an ultraviolet light source operating at $254 \mathrm{~nm}$. Flash column chromatography was performed using silica gel (particle size: $0.035-0.070 \mathrm{~mm}$ ). ${ }^{1} \mathrm{H}$ NMR spectra were recorded on spectrometers operating at $400 \mathrm{MHz}$ or $300 \mathrm{MHz}$ for ${ }^{1} \mathrm{H}$ NMR spectra. All ${ }^{1} \mathrm{H}$ NMR spectra were recorded in deuterated chloro- form $\left(\mathrm{CDCl}_{3}\right)$, with all chemical shift values reported in parts per million referenced against $0.03 \%$ tetramethylsilane (TMS) as an internal standard. All ${ }^{13} \mathrm{C}$ NMR spectra were recorded at 75 or $101 \mathrm{MHz}$ with chemical shifts reported on the $\delta$ scale in parts per million (ppm) relative to the central signal of $\mathrm{CDCl}_{3}$ taken as $77.0 \mathrm{ppm}$. Coupling constants $J$ are reported in hertz $(\mathrm{Hz})$. Commonly used abbreviations in assignments include: $\mathrm{s}=$ singlet, $\mathrm{d}=$ doublet, $\mathrm{t}=$ triplet, $\mathrm{q}=$ quartet, $\mathrm{p}$ $=$ pentet, $\mathrm{m}=$ multiplet. Infrared spectra were recorded where all predominant absorptions are reported in terms of wavenumbers $\left(\mathrm{v} / \mathrm{cm}^{-}\right.$ $\left.{ }^{1}\right)$. High-resolution mass spectra (HRMS) were recorded and are quoted as the relative abundance $(m / z)$. HRMS was performed only on novel compounds where no MS data were available. Melting points were recorded and are reported without correction. UV spectra were recorded using an Agilent Cary $100 \mathrm{UV} /$ vis spectrophotometer, using quartz cuvettes of $1 \mathrm{~cm}$ path length $(l)$. The data were collected over the wavelength $(\lambda)$ range $200-800 \mathrm{~nm}$ at a scan rate of $600 \mathrm{~nm} \mathrm{~min}^{-1}$ and at data intervals of $1.0 \mathrm{~nm}$. The data were processed using Agilent Cary WinUV software version 12.00 , and a plot of absorption (A) versus $\lambda$ was obtained. The molar absorption coefficient $(\varepsilon)$ at each $\lambda_{\max }$ was determined by using the formula $A=\varepsilon^{*} l^{*} \mathrm{M}$, where $\mathrm{M}=$ molarity. To prepare the hydroxybenzophenones $9, \mathbf{1 8}$, and 19 and the hydroxyxanthones $\mathbf{2 2}, \mathbf{2 3}$, and $\mathbf{2 4}$ for UV absorption analysis, each compound was dissolved in $1 \mathrm{~mL}$ of chloroform to obtain a stock solution of $1 \mathrm{mg} \mathrm{mL}^{-1}$. The stock solution was then appropriately diluted to a concentration of $10 \mathrm{ppm}$. All samples were thus analyzed for their UV absorption properties at a concentration of $10 \mathrm{ppm}$.

\section{2-Hydroxy-4-pentadecylbenzaldehyde $(11)^{12}$}

Method 1: To a solution of hydrogenated cardanol (12; $10 \mathrm{~g}, 32.8$ mmol, 1.0 equiv) in anhyd toluene $(125 \mathrm{~mL})$ were added $\mathrm{SnCl}_{4}(0.854$ $\mathrm{g}, 3.28 \mathrm{mmol}, 0.4 \mathrm{~mL}, 0.1$ equiv) and $\mathrm{Et}_{3} \mathrm{~N}(6.97 \mathrm{~mL}, 0.4 \mathrm{M})$ under $\mathrm{N}_{2}$. The mixture was stirred at $\mathrm{rt}$ for $30 \mathrm{~min}$. Paraformaldehyde $(2.17 \mathrm{~g}$, $72.16 \mathrm{mmol}, 2.2$ equiv) was then added, and the mixture stirred for another $30 \mathrm{~min}$ at $\mathrm{rt}$, before being heated to $100^{\circ} \mathrm{C}$. The mixture was then stirred for $8 \mathrm{~h}$, and the reaction was then quenched with $1 \mathrm{M}$ aq $\mathrm{HCl}(100 \mathrm{~mL})$. The mixture was extracted with EtOAc $(3 \times 100 \mathrm{~mL})$, and the combined organic layers were washed sequentially with $\mathrm{H}_{2} \mathrm{O}$ $(100 \mathrm{~mL})$ and brine $(100 \mathrm{~mL})$ then dried $\left(\mathrm{MgSO}_{4}\right)$, filtered, and concentrated in vacuo. The compound was purified by column chromatography (silica gel, 5\% EtOAc-hexane) to give a white solid; yield: 7.4 $\mathrm{g}(67 \%)$.

Method 2: A flask purged with inert gas was charged with paraformaldehyde ( $295.5 \mathrm{mg}, 9.84 \mathrm{mmol}, 3.0$ equiv) and anhyd $\mathrm{MgCl}_{2}$ (624.6 $\mathrm{mg}, 6.56 \mathrm{mmol}, 2.0$ equiv) in a glovebox. Anhyd THF $(20 \mathrm{~mL})$ was then added, and the mixture was stirred at rt. $\mathrm{Et}_{3} \mathrm{~N}(663.8 \mathrm{mg}, 0.9 \mathrm{~mL}, 6.56$ mmol, 2.0 equiv) was added dropwise by syringe, and the mixture was stirred for $10 \mathrm{~min}$. Hydrogenated cardanol (12; $1.0 \mathrm{~g}, 3.28 \mathrm{mmol}$, 1.0 equiv) was then added portionwise and the mixture was heated to $75{ }^{\circ} \mathrm{C}$ and stirred for $2.5 \mathrm{~h}$. Upon completion, the reaction was quenched with $1 \mathrm{M}$ aq $\mathrm{HCl}(10 \mathrm{~mL})$ and extracted with EtOAc $(3 \times 50$ $\mathrm{mL})$. The organic layers were washed with $\mathrm{H}_{2} \mathrm{O}(50 \mathrm{~mL})$ and brine $(50$ $\mathrm{mL})$ then dried $\left(\mathrm{MgSO}_{4}\right)$, filtered, and concentrated in vacuo. The product was purified by crystallization from $\mathrm{MeOH}$ to give a white solid; yield: $740 \mathrm{mg}$ (72\%); $\mathrm{mp} 51-52{ }^{\circ} \mathrm{C} ; R_{f}=0.86$ (20\% EtOAc-hexane).

${ }^{1} \mathrm{H} \mathrm{NMR}\left(300 \mathrm{MHz}, \mathrm{CDCl}_{3}\right): \delta=11.04(\mathrm{~s}, 1 \mathrm{H}, \mathrm{OH}), 9.80(\mathrm{~s}, 1 \mathrm{H}, \mathrm{CHO})$, $7.41\left(\mathrm{~d}, J=7.8,1 \mathrm{H}, \mathrm{ArH}-1^{\prime}\right), 6.83-6.77\left(\mathrm{~m}, 2 \mathrm{H}, \mathrm{ArH}-2^{\prime}, 3^{\prime}\right), 2.60(\mathrm{t}, J=$ 7.7, $2 \mathrm{H}), 1.61$ (p, J = 6.9, $2 \mathrm{H}), 1.25$ (s, $24 \mathrm{H}), 0.88(\mathrm{t}, J=6.4,3 \mathrm{H}, \mathrm{Me})$.

${ }^{13} \mathrm{C}$ NMR $\left(75 \mathrm{MHz}, \mathrm{CDCl}_{3}\right): \delta=195.7(\mathrm{C}=\mathrm{O}), 161.8(\mathrm{ArC}-\mathrm{OH}), 153.8$, 133.6, 120.5, 118.9, 117.1, 36.5, 32.0, 30.7, 29.8, 29.3, 22.8, 14.2 . 


\section{2-Bromo-1,4-dimethoxybenzene $\mathbf{( 1 0}^{18}$}

NBS (7.0 g, $39.8 \mathrm{mmol}, 1.1$ equiv) was added to a solution of 1,4-dimethoxybenzene ( $5.0 \mathrm{~g}, 36.2 \mathrm{mmol}, 1.0$ equiv) in anhyd $\mathrm{CH}_{2} \mathrm{Cl}_{2}(80 \mathrm{~mL})$, and the mixture was stirred at the reflux for $72 \mathrm{~h}$. After cooling, the reaction was quenched with sat. aq $\mathrm{NaSO}_{3}(40 \mathrm{~mL})$ and extracted with $\mathrm{CH}_{2} \mathrm{Cl}_{2}(3 \times 40 \mathrm{~mL})$. The organic layers were washed sequentially with $\mathrm{H}_{2} \mathrm{O}(50 \mathrm{~mL})$ and brine $(50 \mathrm{~mL})$ then dried $\left(\mathrm{MgSO}_{4}\right)$, filtered, and concentrated in vacuo. The crude product was purified by column chromatography (silica gel, 20\% EtOAc-hexane) to give a yellow oil; yield: $5.6 \mathrm{~g}(72 \%) ; R_{f}=0.76$ (20\% EtOAc-hexane).

${ }^{1} \mathrm{H} \mathrm{NMR}\left(300 \mathrm{MHz}, \mathrm{CDCl}_{3}\right): \delta=7.08(\mathrm{dd}, J=2.1,1.3,1 \mathrm{H}, \mathrm{ArH}), 6.75(\mathrm{~m}$, $2 \mathrm{H}, \mathrm{ArH}$ ), 3.76 (s, $3 \mathrm{H}, \mathrm{OMe}$ ), 3.68 (s, $3 \mathrm{H}, \mathrm{OMe}$ ).

${ }^{13} \mathrm{C}$ NMR $\left(75 \mathrm{MHz}, \mathrm{CDCl}_{3}\right.$ ): $\delta=153.9$ (ArC-OMe), 150.2 (ArC-OMe), 119.0, 113.4, 112.8, 111.8, 56.61 (OMe), 55.69 (OMe).

\section{2-[(2,5-Dimethoxyphenyl)(hydroxy)methyl]-5-pentadecylphenol (13)}

All glassware was oven-dried for a minimum of $2 \mathrm{~h}$ before setting up this reaction. An oven-dried, three-necked round-bottomed flask was charged with $\mathrm{Mg}$ turnings (58.3 mg, $2.4 \mathrm{mmol}, 4.0$ equiv) and one granule of $\mathrm{I}_{2}$ dissolved in anhyd $\mathrm{Et}_{2} \mathrm{O}(5 \mathrm{~mL})$. To this suspension was added dropwise a solution of 2-bromo-1,4-dimethoxybenzene (10; $520.9 \mathrm{mg}, 2.4 \mathrm{mmol}, 4.0$ equiv) in anhyd $\mathrm{Et}_{2} \mathrm{O}(1.5 \mathrm{~mL})$. The mixture was gently heated for $4 \mathrm{~h}$, and the surfaces of Mg turnings were repeatedly scratched using a glass rod, until the first signs of Grignard reagent formation were observed. After complete formation of the Grignard reagent, the mixture was cooled to $0{ }^{\circ} \mathrm{C}$ and a solution of 2hydroxy-4-pentadecylbenzaldehyde $(11 ; 200 \mathrm{mg}, 0.60 \mathrm{mmol}, 1.0$ equiv) in anhyd THF (1.5 mL) was added dropwise. The resulting mixture was refluxed for $90 \mathrm{~min}$, and then stirred overnight at rt. Upon completion of the reaction, the mixture was cooled to $0{ }^{\circ} \mathrm{C}$ and sat. aq $\mathrm{NH}_{4} \mathrm{Cl}(20 \mathrm{~mL})$ was added to quench the reaction. The organic material was extracted with EtOAc $(3 \times 50 \mathrm{~mL})$, and the combined organic layers were washed with $\mathrm{H}_{2} \mathrm{O}(50 \mathrm{~mL})$ and brine $(50 \mathrm{~mL})$ then dried $\left(\mathrm{MgSO}_{4}\right)$, filtered, and concentrated in vacuo. The crude product was purified by column chromatography (silica gel, 10\% EtOAc-hexane) to yield a cream solid; yield: $220 \mathrm{mg}(78 \%) ; R_{f}=0.49$ (20\% EtOAc-hexane); $\mathrm{mp} 78-79^{\circ} \mathrm{C}$.

FTIR (solid): 3353 (O-H), 3185 (O-H), 1501 (C=C), 1252 (C-O), 1225 $(\mathrm{C}-\mathrm{O}) \mathrm{cm}^{-1}$.

$\left.{ }^{1} \mathrm{H} \mathrm{NMR} \mathrm{(300} \mathrm{MHz,} \mathrm{CDCl} 3\right): \delta=8.20(\mathrm{~s}, 1 \mathrm{H}, \mathrm{C}-\mathrm{OH}), 6.85-6.55(\mathrm{~m}, 6 \mathrm{H}$, $\operatorname{ArH}), 6.12(\mathrm{~d}, J=4.5,1 \mathrm{H}, \mathrm{ArOH}), 4.14\left(\mathrm{~d}, J=4.6,1 \mathrm{H}, \mathrm{H}-1^{\prime}\right), 3.76(\mathrm{~s}, 3 \mathrm{H}$, OMe), 3.65 (s, 3 H, OMe), 2.52 (t, J = 7.7, 2 H), 1.55 (p, J = 7.0, 2 H), 1.26 $(\mathrm{s}, 24 \mathrm{H}), 0.88(\mathrm{t}, J=6.5,3 \mathrm{H}, \mathrm{Me})$.

${ }^{13} \mathrm{C}$ NMR $\left(75 \mathrm{MHz}, \mathrm{CDCl}_{3}\right): \delta=155.9,153.9,150.9,144.4,130.8,127.6$, 122.8, 119.9, 116.9, 114.6, 113.3, 111.7, 72.8, 55.9, 55.5, 35.6, 32.0, 31.2, 29.4, 22.7.

$\operatorname{HRMS}\left(\mathrm{ESI}^{+}\right)=m / z(\%)=453.3340(100)\left[\mathrm{M}-\mathrm{H}_{2} \mathrm{O}+\mathrm{H}\right]^{+}, 454.3375$ (30). HRMS (ESI?): $m / z$ [M $\left.-\mathrm{H}_{2} \mathrm{O}+\mathrm{H}\right]^{+}$calcd for $\mathrm{C}_{30} \mathrm{H}_{45} \mathrm{O}_{3}: 453.3367$; found: 453.3340 .

\section{(2,5-Dimethoxyphenyl)(2-hydroxy-4-pentadecylphenyl)metha- none (9)}

Method 1 (Oxidation with $\mathrm{MnO}_{2}$ ): Activated $\mathrm{MnO}_{2}(306 \mathrm{mg}, 3.50$ mmol, 8.0 equiv) was added to a solution of secondary alcohol 13 (200 mg, $0.44 \mathrm{mmol}, 1.0$ equiv) in $\mathrm{CH}_{2} \mathrm{Cl}_{2}(10 \mathrm{~mL})$, and the mixture was stirred for $5 \mathrm{~d}$ at $\mathrm{rt}$. Upon completion of the reaction, the mixture was filtered through Celite, concentrated in vacuo under reduced pressure, and purified by column chromatography (silica gel, $15 \%$ EtOAc-hexane) to give a white solid; yield: $145 \mathrm{mg}$ (73\%).
Method 2 (Solvent-free oxidation): Secondary alcohol 3 (200 mg, 0.44 mmol, 1.0 equiv) was ground to a fine powder with a pestle and mortar, then transferred to a round-bottomed flask. Using the same pestle and mortar, $\mathrm{KMnO}_{4}\left(243 \mathrm{mg}, 1.54 \mathrm{mmol}, 3.5\right.$ equiv) and $\mathrm{CuSO}_{4} \cdot 5 \mathrm{H}_{2} \mathrm{O}$ (384.5 mg, $1.54 \mathrm{mmol}, 3.5$ equiv) were ground together until they formed a fine homogeneous powder. This was then added to the round-bottomed flask containing compound $\mathbf{1 3}$, and the mixture was stirred until homogeneous. The mixture was heated at $135^{\circ} \mathrm{C}$ for $2 \mathrm{~h}$, then cooled. EtOAc $(20 \mathrm{~mL})$ was added, and the reaction was quenched with sat. aq $\mathrm{Na}_{2} \mathrm{~S}_{2} \mathrm{O}_{3}(10 \mathrm{~mL})$. The organic material was extracted with EtOAc $(3 \times 20 \mathrm{~mL})$, and the combined organic layers were washed sequentially with $\mathrm{H}_{2} \mathrm{O}(20 \mathrm{~mL})$ and brine $(20 \mathrm{~mL})$ then dried $\left(\mathrm{MgSO}_{4}\right)$, filtered, and concentrated in vacuo under reduced pressure. The crude product was purified by column chromatography (silica gel, 15\% EtOAc-hexane) to give a white solid; yield: $110 \mathrm{mg}$ (53\%).

Method 3 (Fries rearrangement): A microwave tube was carefully charged with $\mathrm{P}_{2} \mathrm{O}_{5}\left(65.1 \mathrm{mg}, 0.46 \mathrm{mmol}, 7.7 \%\right.$ of $\left.\mathrm{MeSO}_{3} \mathrm{H}\right)$ to minimize exposure to the atmosphere. This was quickly followed by the addition of $\mathrm{MeSO}_{3} \mathrm{H}$ ( $573 \mathrm{mg}, 5.96 \mathrm{mmol}, 9.2$ equiv) and benzoate ester $\mathbf{1 5}$ ( $305 \mathrm{mg}, 0.65 \mathrm{mmol}, 1.0$ equiv). The tube was placed in a $50 \mathrm{~W}$ microwave oven and the mixture was heated at $80^{\circ} \mathrm{C}$ for $15 \mathrm{~min}$. The reaction was quenched with $\mathrm{H}_{2} \mathrm{O}(10 \mathrm{~mL})$ and the mixture was extracted with EtOAc $(3 \times 20 \mathrm{~mL})$. The combined organic layers were washed sequentially with sat. aq $\mathrm{NaHCO}_{3}(20 \mathrm{~mL}), \mathrm{H}_{2} \mathrm{O}(20 \mathrm{~mL})$, and brine $(20$ $\mathrm{mL})$, then dried $\left(\mathrm{MgSO}_{4}\right)$ and filtered. After concentration in vacuo, the product was purified by column chromatography (silica gel, $5 \%$ EtOAc-hexane) to give a white solid; yield: $153 \mathrm{mg}$ [50\% (63\% based on recovered starting material)]; $R_{f}=0.66$ (20\% EtOAc-hexane); $\mathrm{mp}$ 61-62 ${ }^{\circ} \mathrm{C}$.

FTIR (solid): = $3001(\mathrm{O}-\mathrm{H}), 2914(\mathrm{C}-\mathrm{H}), 2849(\mathrm{C}-\mathrm{H}), 1632$ (C=O), 1574 $(\mathrm{C}=\mathrm{C}), 1307(\mathrm{C}-\mathrm{O}), 1229(\mathrm{C}-\mathrm{O}), 1099(\mathrm{C}-\mathrm{O}) \mathrm{cm}^{-1}$.

${ }^{1} \mathrm{H} \mathrm{NMR}\left(400 \mathrm{MHz}, \mathrm{CDCl}_{3}\right): \delta=12.16(\mathrm{~s}, 1 \mathrm{H}, \mathrm{OH}), 7.24(\mathrm{~d}, J=8.3,1 \mathrm{H}$, ArH-3'), 7.01-6.97 (m, 1 H), 6.95-6.91 (m, $1 \mathrm{H}), 6.83(\mathrm{~s}, 2 \mathrm{H}$, ArH$\left.1^{\prime}, 4^{\prime}\right), 6.62$ (d, $\left.J=8.2,1 \mathrm{H}, \operatorname{ArH}-2^{\prime}\right), 3.77$ (s, $\left.3 \mathrm{H}, \mathrm{OMe}\right), 3.72$ (s, $3 \mathrm{H}$, OMe), 2.58 (t, J = 7.7, 2 H), 1.61 (p, J = 7.2, 2 H), $1.26(\mathrm{~s}, 24 \mathrm{H}), 0.88$ (t, $J=6.6,3 \mathrm{H}, \mathrm{Me})$.

${ }^{13} \mathrm{C}$ NMR (101 MHz, $\left.\mathrm{CDCl}_{3}\right): \delta=200.9(\mathrm{C}=\mathrm{O}), 163.1(\mathrm{C}-\mathrm{OH}), 153.1$ (ArC-OMe), 153.3, 150.5 (ArC-OMe), 133.7, 128.1, 119.4, 118.0, 117.4, 116.9, 113.9, 113.0, 56.4 (OMe), 55.9 (OMe), 36.3, 31.9, 30.1, 29.7, 29.6, 29.5, 29.4, 29.3, 22.7, 14.1 .

HRMS (ESI $\left.{ }^{+}\right): m / z(\%)=469.3297(90)[\mathrm{M}+\mathrm{H}]^{+}, 470.3340(30)$.

HRMS (ESI?): $m / z[M+H]^{+}$calcd for $\mathrm{C}_{30} \mathrm{H}_{45} \mathrm{O}_{4}$ : 469.3318; found: 469.3297.

\section{2-Methoxy-6-pentadecyl-9H-xanthen-9-one (14)}

In a round-bottomed flask, $\mathrm{CHCl}_{3}(3 \mathrm{~mL})$ and $\mathrm{MeCN}(12 \mathrm{~mL})$ were used to dissolve benzophenone 9 ( $145 \mathrm{mg}, 0.32 \mathrm{mmol}, 1.0$ equiv). $\mathrm{H}_{2} \mathrm{O}$ (6 $\mathrm{mL}$ ) was added to form a suspension to which CAS (810 mg, 1.28 $\mathrm{mmol}, 4.0$ equiv) was added in portions. The mixture was then heated to $70{ }^{\circ} \mathrm{C}$ and stirred for $18 \mathrm{~h}$. Upon completion of the reaction, the mixture was transferred to a separatory funnel, and EtOAc $(50 \mathrm{~mL})$ and $\mathrm{H}_{2} \mathrm{O}(20 \mathrm{~mL})$ were added. The organic layer was separated, washed sequentially with sat. aq $\mathrm{NaHCO}_{3}(20 \mathrm{~mL})$ and brine $(20 \mathrm{~mL})$, dried $\left(\mathrm{MgSO}_{4}\right)$, filtered, and concentrated in vacuo. The crude product was purified by column chromatography (silica gel, 10\% EtOAc-hexane) to give a white solid; yield: $98 \mathrm{mg}(70 \%) ; R_{f}=0.71$ (20\% EtOAchexane); $\operatorname{mp} 94-95^{\circ} \mathrm{C}$.

FTIR (solid): = $2920(\mathrm{C}-\mathrm{H}), 2848(\mathrm{C}-\mathrm{H}), 1651(\mathrm{C}=\mathrm{O}), 1483(\mathrm{C}=\mathrm{C}), 1346$ (C-O), 1315, $1226(\mathrm{C}-\mathrm{O}) \mathrm{cm}^{-1}$. 
${ }^{1} \mathrm{H} \mathrm{NMR}\left(400 \mathrm{MHz}, \mathrm{CDCl}_{3}\right): \delta=8.24\left(\mathrm{~d}, J=8.2,1 \mathrm{H}, \mathrm{ArH}-1^{\prime}\right), 7.71(\mathrm{~s}, 1$ H, ArH-3'), 7.42 (d, J = 9.2, 1 H), 7.33-7.25 (m, $2 \mathrm{H}), 7.20$ (d, $J=8.2,1 \mathrm{H}$, ArH-2'), $3.92(\mathrm{~s}, 3 \mathrm{H}, \mathrm{OMe}), 2.75(\mathrm{t}, J=7.8,2 \mathrm{H}), 1.69$ (p, $J=7.4,2 \mathrm{H})$, $1.25(\mathrm{~s}, 24 \mathrm{H}), 0.88(\mathrm{t}, J=6.6,3 \mathrm{H}, \mathrm{Me})$.

${ }^{13} \mathrm{C}$ NMR $\left(101 \mathrm{MHz}, \mathrm{CDCl}_{3}\right): \delta=177.9(\mathrm{C}=0), 156.3,155.9,151.0$, $151.0,126.5,124.6,124.6,122.2,119.3,119.2,117.0,105.9,55.9$ (OMe), 36.2, 31.9, 30.9, 29.7, 29.7, 29.5, 29.4, 29.4, 29.2, 22.7, 14.1.

HRMS (ESI?): $m / z(\%)=437.3024(100)[\mathrm{M}+\mathrm{H}]^{+}, 438.3057(30)$, 439.3085 (5).

HRMS (ESI?): $m / z[M+H]^{+}$calcd for $\mathrm{C}_{29} \mathrm{H}_{41} \mathrm{O}_{3}:$ 437.3056; found: 437.3024.

\section{3-Pentadecylphenyl 2,5-Dimethoxybenzoate (15)}

Method 1: To a two-necked flask containing 2,5-dimethoxybenzoic acid (657 mg, $3.61 \mathrm{mmol}, 1.1$ equiv) was added TFAA (1.8 mL, 13.12 mmol, 4.0 equiv) under $\mathrm{N}_{2}$, and the solution was stirred for $15 \mathrm{~min}$ at rt. A solution of hydrogenated cardanol $(12 ; 1.0 \mathrm{~g}, 3.28 \mathrm{mmol}, 1.0$ equiv) in anhyd $\mathrm{CH}_{2} \mathrm{Cl}_{2}(20 \mathrm{~mL})$ was added and the mixture was stirred at rt. for $8 \mathrm{~h}$. The reaction was quenched with sat. aq $\mathrm{NaHCO}_{3}$ $(20 \mathrm{~mL})$, and the mixture was extracted with $\mathrm{CH}_{2} \mathrm{Cl}_{2}(3 \times 20 \mathrm{~mL})$. The combined organic layers were washed with $\mathrm{H}_{2} \mathrm{O}(50 \mathrm{~mL})$ and brine $(50 \mathrm{~mL})$, dried $\left(\mathrm{MgSO}_{4}\right)$, filtered, and concentrated in vacuo. The crude product was purified by column chromatography (silica gel, 20\% EtOAc-hexane) to give a pale-yellow low-melting solid; yield: $1.4 \mathrm{~g}$ (93\%).

Method 2: To a two necked flask containing 2,5-dimethoxybenzoic acid (40 mg, $0.22 \mathrm{mmol}, 1.2$ equiv) was added TFAA ( $0.18 \mathrm{~mL}, 1.29$ mmol, 7 equiv) under $\mathrm{N}_{2}$, and the solution was stirred for $15 \mathrm{~min}$ at $\mathrm{rt}$. A solution of hydrogenated cardanol $(12 ; 55 \mathrm{mg}, 0.18 \mathrm{mmol}, 1.0$ equiv) in anhyd toluene ( $3 \mathrm{~mL}$ ) was added, and the mixture stirred at rt for $3 \mathrm{~h}$. The reaction was quenched with sat. aq $\mathrm{NaHCO}_{3}(5 \mathrm{~mL})$ and the mixture was extracted with EtOAc $(3 \times 20 \mathrm{~mL})$. The combined organic extracts were washed with $\mathrm{H}_{2} \mathrm{O}(10 \mathrm{~mL})$ and brine $(10 \mathrm{~mL})$, dried $\left(\mathrm{MgSO}_{4}\right)$, filtered, and concentrated in vacuo. The product was purified by column chromatography (silica gel, 20\% EtOAc-hexane) to give a pale-yellow low-melting solid; yield: $80 \mathrm{mg}(95 \%) ; R_{f}=0.60$ (20\% EtOAc-hexane); $\mathrm{mp} 43-44.5^{\circ} \mathrm{C}$.

FTIR (solid): 2917 (C-H), 2850 (C-H), 1715 (C=O), 1584 (C=C), 1286 (C-O), $1232(\mathrm{C}-\mathrm{O}) \mathrm{cm}^{-1}$.

${ }^{1} \mathrm{H} \mathrm{NMR}\left(300 \mathrm{MHz}, \mathrm{CDCl}_{3}\right): \delta=7.54\left(\mathrm{~d}, J=3.2,1 \mathrm{H}, \mathrm{ArH}-3^{\prime}\right), 7.33-7.26$ (m, $1 \mathrm{H}, \mathrm{ArH}-5^{\prime}$ ), 7.09 (dd, $\left.J=9.0,3.1,2 \mathrm{H}, \mathrm{ArH}-2^{\prime}, 7^{\prime}\right), 7.03$ (dd, $J=7.8$, 1.6, $\left.2 \mathrm{H}, \mathrm{ArH}-4^{\prime}, 6^{\prime}\right), 6.96$ (d, $\left.J=9.1,1 \mathrm{H}, \mathrm{ArH}-1^{\prime}\right), 3.88$ (s, $3 \mathrm{H}, \mathrm{OMe}$ ), 3.81 (s, $3 \mathrm{H}, \mathrm{OMe}$ ), 2.62 (dd, $J=8.8,6.7,2 \mathrm{H}$ ), 1.62 (p, J = 7.3, $2 \mathrm{H}$ ), 1.31 $(\mathrm{s}, 24 \mathrm{H}), 0.93(\mathrm{t}, J=6.8,3 \mathrm{H}, \mathrm{Me})$.

${ }^{13} \mathrm{C}$ NMR $\left(75 \mathrm{MHz}, \mathrm{CDCl}_{3}\right): \delta=164.3(\mathrm{C}=0), 154.3,153.1,151.0,144.6$, 129.1, 125.9, 121.7, 120.3, 119.7, 119.0, 116.3, 114.1, 56.8 (OMe), 55.9 (OMe), 35.8, 32.0, 31.3, 29.7, 29.7, 29.6, 29.5, 29.4, 29.4, 22.7, 14.2.

HRMS (ESI?): $m / z(\%)=469.3299(100)[\mathrm{M}+\mathrm{H}]^{+}, 470.3334(30)$, 471.3362 (5).

HRMS (ESI?): $m / z[M+H]^{+}$calcd for $\mathrm{C}_{30} \mathrm{H}_{45} \mathrm{O}_{4}: 469.3318$; found: 469.3299.

\section{3-Pentadecylphenyl 2,3-dimethoxybenzoate (16)}

Method 1: TFAA ( $2.74 \mathrm{~mL}, 19.7 \mathrm{mmol}, 4.0$ equiv) was added to a twonecked flask containing 2,3-dimethoxybenzoic acid $(987 \mathrm{mg}, 5.41$ mmol, 1.1 equiv) under $\mathrm{N}_{2}$, and the solution was stirred for $15 \mathrm{~min}$ at rt. A solution of hydrogenated cardanol $(12 ; 1.5 \mathrm{~g}, 4.92 \mathrm{mmol}, 1.0$ equiv) in anhyd $\mathrm{CH}_{2} \mathrm{Cl}_{2}(25 \mathrm{~mL})$ was then added and the mixture was stirred at $\mathrm{rt}$ for $18 \mathrm{~h}$. The reaction was quenched with a sat. aq
$\mathrm{NaHCO}_{3}(20 \mathrm{~mL})$, and the mixture was extracted with $\mathrm{CH}_{2} \mathrm{Cl}_{2}(3 \times 25$ $\mathrm{mL})$. The combined organic layers were washed with $\mathrm{H}_{2} \mathrm{O}(20 \mathrm{~mL})$ and brine $(20 \mathrm{~mL})$, then dried $\left(\mathrm{MgSO}_{4}\right)$, filtered, and concentrated in vacuo. The crude product was purified by column chromatography (silica gel, 20\% EtOAc-hexane) to give a white solid; yield: $2.2 \mathrm{~g}$ (96\%).

Method 2: TFAA ( $0.18 \mathrm{~mL}, 1.29 \mathrm{mmol}, 7$ equiv) was added to a twonecked flask containing 2,3-dimethoxybenzoic acid (40 mg, 0.22 mmol, 1.2 equiv) under $\mathrm{N}_{2}$, and the solution was stirred for $15 \mathrm{~min}$ at rt. A solution of hydrogenated cardanol $(12 ; 55 \mathrm{mg}, 0.18 \mathrm{mmol}, 1.0$ equiv) in anhyd toluene ( $3 \mathrm{~mL}$ ) was then added, and the mixture was stirred at rt for $18 \mathrm{~h}$. The reaction was quenched with sat. aq $\mathrm{NaHCO}_{3}$ $(10 \mathrm{~mL})$, and the mixture was extracted with EtOAc $(3 \times 20 \mathrm{~mL})$. The combined organic layers were washed with $\mathrm{H}_{2} \mathrm{O}(10 \mathrm{~mL})$ and brine $(10 \mathrm{~mL})$ then dried $\left(\mathrm{MgSO}_{4}\right)$, filtered, and concentrated in vacuo. The product was purified by column chromatography (silica gel, $20 \%$ EtOAc-hexane) to give a white solid; yield: $70 \mathrm{mg}(83 \%) ; R_{f}=0.64(20 \%$ EtOAc-hexane); $\mathrm{mp} 65.6-66.4^{\circ} \mathrm{C}$.

FTIR (solid): $2921(\mathrm{C}-\mathrm{H}), 1731(\mathrm{C}=\mathrm{O}), 1583$ (C=C), 1307 (C-O), 1251 (C-O), 1210 (C-O), 1096 (C-O) $\mathrm{cm}^{-1}$.

${ }^{1} \mathrm{H}$ NMR (300 MHz, $\mathrm{CDCl}_{3}$ ): $\delta=7.52(\mathrm{dd}, J=6.9,2.5,1 \mathrm{H}, \mathrm{ArH}), 7.35-$ 7.28 (m, $1 \mathrm{H}, \mathrm{ArH}), 7.19-7.11$ (m, $2 \mathrm{H}, \mathrm{ArH}), 7.10-7.02(\mathrm{~m}, 3 \mathrm{H}, \mathrm{ArH})$, 3.96 (s, $3 \mathrm{H}, \mathrm{OMe}), 3.92$ (s, $3 \mathrm{H}, \mathrm{OMe}), 2.62(\mathrm{t}, J=7.7,2 \mathrm{H}), 1.62$ (p, $J=$ 8.7, $3 \mathrm{H}), 1.26(\mathrm{~s}, 24 \mathrm{H}), 0.88(\mathrm{t}, J=6.8 \mathrm{~Hz}, 3 \mathrm{H}, \mathrm{Me})$.

${ }^{13} \mathrm{C}$ NMR $\left(75 \mathrm{MHz}, \mathrm{CDCl}_{3}\right): \delta=164.6(\mathrm{C}=0), 153.7,150.9,149.7,144.8$, 129.1, 126.0, 125.5, 123.9, 122.6, 121.6, 118.9, 116.4, 61.6 (OMe), 56.1 (OMe), 35.8, 31.9, 31.3, 30.9, 29.7, 29.7, 29.6, 29.5, 29.4, 29.3, 22.7, 14.1.

HRMS (ESI?): $m / z(\%)=469.3304(100)[\mathrm{M}+\mathrm{H}]^{+}, 470.3339(30)$, 471.3369 (5).

HRMS (ESI?): $m / z[M+H]^{+}$calcd for $\mathrm{C}_{30} \mathrm{H}_{45} \mathrm{O}_{4}$ : 469.3318; found: 469.3304 .

\section{3-Pentadecylphenyl 2,4,5-Trimethoxybenzoate (17)}

Method 1: TFAA ( $2.74 \mathrm{~mL}, 19.7 \mathrm{mmol}, 4.0$ equiv) was added to a twonecked flask containing 2,4,5-trimethoxybenzoic acid (1.15 g, 5.41 mmol, 1.1 equiv) under $\mathrm{N}_{2}$, and the solution was stirred for $15 \mathrm{~min}$ at rt. A solution of hydrogenated cardanol $(12 ; 1.5 \mathrm{~g}, 4.92 \mathrm{mmol}, 1.0$ equiv) in anhyd $\mathrm{CH}_{2} \mathrm{Cl}_{2}(20 \mathrm{~mL})$ was added, and the mixture was stirred at $\mathrm{rt}$ for $18 \mathrm{~h}$. The reaction was quenched with a sat. aq $\mathrm{NaH}-$ $\mathrm{CO}_{3}(20 \mathrm{~mL})$ and the mixture was extracted with $\mathrm{CH}_{2} \mathrm{Cl}_{2}(3 \times 20 \mathrm{~mL})$. The combined organic layers were washed with $\mathrm{H}_{2} \mathrm{O}(20 \mathrm{~mL})$ and brine $(20 \mathrm{~mL})$ then dried $\left(\mathrm{MgSO}_{4}\right)$, filtered, and concentrated in vacuo. The crude product was purified by column chromatography (silica gel, 20\% EtOAc-hexane) to give a white solid; yield: $2.3 \mathrm{~g}$ (94\%).

Method 2: TFAA ( $0.18 \mathrm{~mL}, 1.29 \mathrm{mmol}, 7$ equiv) was added to a twonecked flask containing 2,4,5-trimethoxybenzoic acid (47 mg, 0.22 mmol, 1.2 equiv) under $\mathrm{N}_{2}$, and the solution was stirred for $15 \mathrm{~min}$ at rt. A solution of hydrogenated cardanol $(12 ; 55 \mathrm{mg}, 0.18 \mathrm{mmol}, 1.0$ equiv) in anhyd toluene ( $3 \mathrm{~mL}$ ) was added and the mixture was stirred at $\mathrm{rt}$ for $18 \mathrm{~h}$. The reaction was quenched with sat. aq $\mathrm{NaHCO}_{3}$ $(10 \mathrm{~mL})$, and the mixture was extracted with EtOAc $(3 \times 20 \mathrm{~mL})$. The combined organic layers were washed with $\mathrm{H}_{2} \mathrm{O}(10 \mathrm{~mL})$ and brine $(10 \mathrm{~mL})$, then dried $\left(\mathrm{MgSO}_{4}\right)$, filtered, and concentrated in vacuo. The crude product was purified by column chromatography (silica gel, $20 \%$ EtOAc-hexane) to give a white solid; yield: $70 \mathrm{mg}(78 \%) ; R_{f}=0.24$ (20\% EtOAc-hexane); $\mathrm{mp} 62.3-62.6^{\circ} \mathrm{C}$.

FTIR (solid): 2919 (C-H), 2850 (C-H), 1707 (C=O), 1578 (C=C), 1268 (C-O), 1238 (C-O), 1205 (C-O) $\mathrm{cm}^{-1}$. 
${ }^{1} \mathrm{H}$ NMR $\left(400 \mathrm{MHz}, \mathrm{CDCl}_{3}\right): \delta=7.59\left(\mathrm{~s}, 1 \mathrm{H}, \mathrm{ArH}-1^{\prime}\right), 7.29(\mathrm{dd}, J=15.3$, 7.6, $1 \mathrm{H}, \mathrm{ArH}), 7.08-6.99$ (m, $3 \mathrm{H}, \mathrm{ArH}), 6.58$ (s, $\left.1 \mathrm{H}, \mathrm{ArH}-2^{\prime}\right), 3.97$ (s, 3 $\mathrm{H}, \mathrm{OMe}), 3.93$ (s, $3 \mathrm{H}, \mathrm{OMe}), 3.90$ (s, $3 \mathrm{H}, \mathrm{OMe}), 2.62(\mathrm{t}, J=7.7,2 \mathrm{H})$, $1.62(\mathrm{p}, J=8.7,3 \mathrm{H}), 1.26(\mathrm{~s}, 24 \mathrm{H}), 0.88(\mathrm{t}, J=6.8,3 \mathrm{H}, \mathrm{Me})$.

${ }^{13} \mathrm{C}$ NMR $\left(75 \mathrm{MHz}, \mathrm{CDCl}_{3}\right.$ ): $\delta=163.9(\mathrm{C}=\mathrm{O}), 156.6$ (ArC-OMe), 154.2 (ArC-OMe), 151.0, 144.6, 142.6 (ArC-OMe), 129.0, 125.7, 121.8, 119.1, 114.6, 109.8, 97.8, 57.1 (OMe), 56.5 (OMe), 56.1 (OMe), 35.8, 31.9, 31.3, 29.7, 29.7, 29.6, 29.5, 29.4, 22.7, 14.1 .

HRMS: (ESI?): $m / z(\%)=499.3402(100)[\mathrm{M}+\mathrm{H}]^{+}, 500.3429$ (30).

HRMS: (ESI?): $m / z[\mathrm{M}+\mathrm{H}]^{+}$calcd for $\mathrm{C}_{31} \mathrm{H}_{47} \mathrm{O}_{5}:$ 499.3423; found: 499.3402.

\section{(2,3-Dimethoxyphenyl)(2-hydroxy-4-pentadecylphenyl)metha- none (18)}

A one-necked round-bottomed flask was charged with benzoate ester 16 ( $1.0 \mathrm{~g}, 2.13 \mathrm{mmol}, 1.0$ equiv). This was then dissolved in anhyd toluene $(8.5 \mathrm{~mL})$, placed in an oil bath, and heated to $100{ }^{\circ} \mathrm{C}$ with stirring for $5 \mathrm{~min}$. Triflic acid $(0.32 \mathrm{~mL})$ was then added, and the mixture was stirred at $100{ }^{\circ} \mathrm{C}$ for $45 \mathrm{~min}$. The reaction was quenched with $\mathrm{H}_{2} \mathrm{O}(10$ $\mathrm{mL})$ followed by sat. aq $\mathrm{NaHCO}_{3}(10 \mathrm{~mL})$, and the mixture was extracted with EtOAc $(3 \times 20 \mathrm{~mL})$. The combined organic layers were washed with $\mathrm{H}_{2} \mathrm{O}(15 \mathrm{~mL})$ and brine $(15 \mathrm{~mL})$, then dried $\left(\mathrm{MgSO}_{4}\right)$, filtered, and concentrated in vacuo. The crude product was purified by column chromatography (silica gel, 5\% EtOAc-hexane) to yield a clear lowmelting solid; yield: $630 \mathrm{mg}$ (63\%); $R_{f}=0.70$ (20\% EtOAc-hexane); mp 38-39 ${ }^{\circ} \mathrm{C}$.

FTIR (solid): 2917 (C-H), 2849 (C-H), 1634 (C=O), 1580 (C=C), 1364 (C-O), 1269 (C-O), $1229(\mathrm{C}-\mathrm{O}), 1075(\mathrm{C}-\mathrm{O}) \mathrm{cm}^{-1}$.

${ }^{1} \mathrm{H} \mathrm{NMR}\left(400 \mathrm{MHz}, \mathrm{CDCl}_{3}\right): \delta=12.20(\mathrm{~s}, 1 \mathrm{H}, \mathrm{OH}), 7.23(\mathrm{~d}, J=8.2,1 \mathrm{H}$, ArH-1'), 7.13 (td, $J=7.9,1.8,1 \mathrm{H}, \mathrm{ArH}), 7.04(\mathrm{~d}, J=8.2,1 \mathrm{H}, \mathrm{ArH}), 6.86$ (s, $1 \mathrm{H}, \mathrm{ArH}), 6.84$ (s, $\left.1 \mathrm{H}, \mathrm{ArH}-3^{\prime}\right), 6.61$ (d, J = 8.3, $1 \mathrm{H}, \mathrm{ArH}-2$ '), 3.91 (s, $3 \mathrm{H}, \mathrm{OMe}), 3.79$ (s, $3 \mathrm{H}, \mathrm{OMe}), 2.58(\mathrm{t}, J=7.8,2 \mathrm{H}), 1.60$ (p, J = 7.7, $2 \mathrm{H}$ ), $1.26(\mathrm{~s}, 24 \mathrm{H}), 0.87(\mathrm{t}, J=7.1,3 \mathrm{H}, \mathrm{Me})$.

${ }^{13} \mathrm{C}$ NMR $\left(101 \mathrm{MHz}, \mathrm{CDCl}_{3}\right): \delta=201.0(\mathrm{C}=\mathrm{O}), 163.1(\mathrm{ArC}-\mathrm{OH}), 153.4$ (ArC-OMe), 152.8 (ArC-OMe), 146.2, 133.8 (ArC-1'), 133.3, 124.0, 119.9, 119.5, 118.1, 117.4, 114.1, 61.8 (OMe), 55.9 (OMe), 36.3, 32.0, 30.6, 29.7, 29.6, 29.5, 29.4, 29.3, 22.7, 14.2 .

HRMS (ESI?): $m / z(\%)=469.3292(100)[M+H]^{+}, 470.3327$ (30), 471.3355 (5).

HRMS (ESI?): $m / z[M+H]^{+}$calcd for $\mathrm{C}_{30} \mathrm{H}_{45} \mathrm{O}_{4}$ : 469.3318; found: 469.3292 .

\section{(2-Hydroxy-4-pentadecylphenyl)(2,4,5-trimethoxyphenyl)metha- none (19)}

A small reaction tube was charged with benzoate ester $\mathbf{1 7}$ (300 mg, $0.60 \mathrm{mmol}$ ). Anhyd $\mathrm{MeCN}(2.5 \mathrm{~mL})$ was added and the mixture was stirred at $70{ }^{\circ} \mathrm{C}$ until the solid completely dissolved. Triflic acid (0.09 $\mathrm{mL}$ ) was then added and the resulting mixture was stirred for $45 \mathrm{~min}$ at $70{ }^{\circ} \mathrm{C}$. The reaction was quenched with $\mathrm{H}_{2} \mathrm{O}(5 \mathrm{~mL})$ followed by sat. aq $\mathrm{NaHCO}_{3}(5 \mathrm{~mL})$, and mixture was extracted with EtOAc $(3 \times 15 \mathrm{~mL})$. The combined organic layers were washed with $\mathrm{H}_{2} \mathrm{O}(5 \mathrm{~mL})$ and brine $(5 \mathrm{~mL})$, then dried $\left(\mathrm{MgSO}_{4}\right)$, filtered, and concentrated in vacuo. The crude product was purified by column chromatography (silica gel, $20 \%$ EtOAc-hexane) to give a white solid; yield: $60 \mathrm{mg}(20 \%) ; R_{f}=0.36$ (20\% EtOAc-hexane); mp $62.8-63.8^{\circ} \mathrm{C}$.

FTIR (solid): 2915 (C-H), 2849 (C-H), 1662 (C=O), 1508 (C=C), 1307 (C-O), $1263(\mathrm{C}-\mathrm{O}), 1218(\mathrm{C}-\mathrm{O}), 1097(\mathrm{C}-\mathrm{O}) \mathrm{cm}^{-1}$.
${ }^{1} \mathrm{H} \mathrm{NMR}\left(400 \mathrm{MHz}, \mathrm{CDCl}_{3}\right): \delta=12.25(\mathrm{~s}, 1 \mathrm{H}, \mathrm{OH}), 7.31(\mathrm{~d}, J=8.2,1 \mathrm{H}$, ArH-5'), 6.87 (s, 1 H, ArH-2'), 6.84 (s, 1 H, ArH-3'), 6.63 (d, J = 8.3, 1 H, ArH-4'), 6.59 (s, $\left.1 \mathrm{H}, \mathrm{ArH}-1^{\prime}\right), 3.97$ (s, $\left.3 \mathrm{H}, \mathrm{OMe}\right), 3.84$ (s, $3 \mathrm{H}, \mathrm{OMe}$ ), $3.76(\mathrm{~s}, 3 \mathrm{H}, \mathrm{OMe}), 2.59(\mathrm{t}, J=7.8,2 \mathrm{H}), 1.62(\mathrm{~m}, 2 \mathrm{H}), 1.25(\mathrm{~s}, 24 \mathrm{H})$, $0.88(\mathrm{t}, J=6.6,3 \mathrm{H}, \mathrm{Me})$.

${ }^{13} \mathrm{C}$ NMR (101 MHz, $\left.\mathrm{CDCl}_{3}\right): \delta=200.4(\mathrm{C}=\mathrm{O}), 163.0(\mathrm{C}-\mathrm{OH}), 152.9$ (ArC-OMe), 151.9 (ArC-OMe), 151.8 (ArC-OMe), 143.0, 133.7, 119.3, 118.3, 117.4 (C-3'), 112.6 (C-2'), $97.5\left(\mathrm{C}-1^{\prime}\right), 56.7$ (OMe), 56.5 (OMe), 56.2 (OMe), 36.3, 31.9, 31.0, 30.6, 29.7, 29.7, 29.6, 29.5, 29.4, 29.3, 22.7, 14.1 .

HRMS (ESI?): $m / z(\%)=499.3412(100)[\mathrm{M}+\mathrm{H}]^{+}, 500.3445(30)$, 501.3470 (5).

HRMS (ESI?): $m / z$ calcd $[\mathrm{M}+\mathrm{H}]^{+}$for $\mathrm{C}_{31} \mathrm{H}_{47} \mathrm{O}_{5}$ : 499.3423; found: 499.3412 .

\section{5-Methoxy-3-pentadecyl-9H-xanthen-9-one (20)}

Benzophenone 18 (113 mg, $0.24 \mathrm{mmol}, 1.0$ equiv) was dissolved in $\mathrm{CHCl}_{3}(2.5 \mathrm{~mL})$ and $\mathrm{MeCN}(10 \mathrm{~mL}) . \mathrm{H}_{2} \mathrm{O}(5 \mathrm{~mL})$ was then added to form a suspension to which CAS ( $607 \mathrm{mg}, 0.96 \mathrm{mmol}, 4.0$ equiv) was added in portions. The mixture was heated to $70{ }^{\circ} \mathrm{C}$ and stirred for $18 \mathrm{~h}$. Upon completion of the reaction, the mixture was transferred to a separatory funnel and EtOAc $(20 \mathrm{~mL})$ and $\mathrm{H}_{2} \mathrm{O}(10 \mathrm{~mL})$ were added. The separated organic layer was washed with sat. aq $\mathrm{NaHCO}_{3}(10 \mathrm{~mL})$ and brine $(10 \mathrm{~mL})$, then dried $\left(\mathrm{MgSO}_{4}\right)$, filtered, and concentrated in vacuo. The crude product was purified by column chromatography (silica gel, 15\% EtOAc-hexane) to give a white solid; yield: $60 \mathrm{mg}$ (57\%); $R_{f}=0.52$ (20\% EtOAc-hexane); $\mathrm{mp} 103-104.8^{\circ} \mathrm{C}$.

FTIR (solid): 2916 (C-H), 2849 (C-H), 1661 (C=O), 1508 (C=C), 1270 (C-O), $1198(\mathrm{C}-\mathrm{O}), 1110(\mathrm{C}-\mathrm{O}) \mathrm{cm}^{-1}$.

${ }^{1} \mathrm{H}$ NMR $\left(400 \mathrm{MHz}, \mathrm{CDCl}_{3}\right): \delta=8.24\left(\mathrm{~d}, J=8.2,1 \mathrm{H}, \mathrm{ArH}-1^{\prime}\right), 7.91(\mathrm{~d}, J=$ 7.9, 1 H, ArH-3'), 7.44 (s, $\left.1 \mathrm{H}, \mathrm{ArH}-2^{\prime}\right), 7.32-7.18$ (m, $3 \mathrm{H}$ ), 4.05 (s, $3 \mathrm{H}$, OMe), 2.75 (t, J = 7.7 Hz, $2 \mathrm{H}$ ), 1.69 (p, J = 7.6, 2 H), 1.25 (s, $24 \mathrm{H}), 0.90-$ $0.84(\mathrm{~m}, 3 \mathrm{H}, \mathrm{Me})$.

${ }^{13} \mathrm{C} \mathrm{NMR}\left(101 \mathrm{MHz}, \mathrm{CDCl}_{3}\right): \delta=177.0(\mathrm{C}=0), 156.1,151.3,148.6(\mathrm{ArC}-$ OMe), 146.5, 126.4, 125.1, 123.3, 122.8, 119.6, 117.7, 117.4, 115.1, 56.4 (OMe), 36.2, 31.9, 30.8, 29.7, 29.7, 29.6, 29.5, 29.4, 29.2, 22.7, 14.2 .

HRMS (ESI?): $m / z(\%)=437.3050(100)[\mathrm{M}+\mathrm{H}]^{+}, 438.3071$ (30).

HRMS (ESI?): $m / z[M+H]^{+}$calcd for $\mathrm{C}_{29} \mathrm{H}_{41} \mathrm{O}_{3}: 437.3056$; found: 437.3050.

\section{2,3-Dimethoxy-6-pentadecyl-9H-xanthen-9-one (21)}

Benzophenone 19 (159 mg, $0.32 \mathrm{mmol}, 1.0$ equiv) was dissolved in $\mathrm{CHCl}_{3}(3 \mathrm{~mL})$ and $\mathrm{MeCN}(12 \mathrm{~mL})$ in a round-bottomed flask. $\mathrm{H}_{2} \mathrm{O}(6$ $\mathrm{mL}$ ) was added to form a suspension to which CAS $(810 \mathrm{mg}, 1.28$ $\mathrm{mmol}, 4.0$ equiv) was added in portions. The mixture was then heated to $70{ }^{\circ} \mathrm{C}$ and stirred for $18 \mathrm{~h}$. Upon completion of the reaction, the mixture was transferred to a separatory funnel and EtOAc $(20 \mathrm{~mL})$ and $\mathrm{H}_{2} \mathrm{O}(10 \mathrm{~mL})$ were added. The organic layer was washed with sat. aq $\mathrm{NaHCO}_{3}(10 \mathrm{~mL})$ and brine $(10 \mathrm{~mL})$, then dried $\left(\mathrm{MgSO}_{4}\right)$, filtered, and concentrated in vacuo. The crude product was purified by column chromatography (silica gel, 15\% EtOAc-hexane) to give a white solid; yield: $110 \mathrm{mg}$ (74\%); $R_{f}=0.33$ (20\% EtOAc-hexane); $\mathrm{mp} 96.5-97.7^{\circ} \mathrm{C}$.

FTIR (solid): 2916 (C-H), 2849 (C-H), 1646 (C=O), 1508 (C=C), 1270 (C-O), $1208(\mathrm{C}-\mathrm{O}), 1170(\mathrm{C}-\mathrm{O}) \mathrm{cm}^{-1}$.

${ }^{1} \mathrm{H} \mathrm{NMR}\left(400 \mathrm{MHz}, \mathrm{CDCl}_{3}\right): \delta=8.24(\mathrm{~d}, J=8.1,1 \mathrm{H}, \operatorname{ArH}-5$ ), $7.67(\mathrm{~s}, 1$ H, ArH-1'), 7.26 (d, J = 7.3, $\left.1 \mathrm{H}, \mathrm{ArH}-3^{\prime}\right), 7.20$ (d, J = 8.2, $\left.1 \mathrm{H}, \mathrm{ArH}-4^{\prime}\right)$, 6.90 (s, 1 H, ArH-2'), 4.02 (s, 3 H, OMe), 4.00 (s, 3 H, OMe), 2.75 (t, $J=$ 7.7, 2 H), 1.69 (p, J = 7.5, 2 H), 1.25 (s, 24 H), 0.88 (t, J = 6.6, 3 H, Me). 
${ }^{13} \mathrm{C}$ NMR (101 MHz, $\left.\mathrm{CDCl}_{3}\right): \delta=176.0(\mathrm{C}=0), 156.2,155.2$ (ArC-OMe), 152.4, 150.4, 146.6 (ArC-OMe), 126.3, 124.7, 119.5, 116.8, 115.0, 105.4, 99.6, 56.5 (OMe), 56.3 (OMe), 36.2, 31.9, 31.0, 29.7, 29.7, 29.6, $29.5,29.4,29.3,22.7,14.1$.

HRMS (ESI?): $m / z(\%)=467.3145(100)[\mathrm{M}+\mathrm{H}]^{+}, 468.3178(30)$, 469.3209 (5).

HRMS (ESI?): $m / z$ [M $+\mathrm{H}]^{+}$calcd for $\mathrm{C}_{30} \mathrm{H}_{43} \mathrm{O}_{4}: 467.3161$; found: 467.3145 .

\section{1-Hydroxy-7-methoxy-3-pentadecyl-9H-xanthen-9-one (22)}

A tube was charged with xanthone 14 (30 mg, $0.069 \mathrm{mmol}, 1.0$ equiv), PIFA (36 mg, $0.084 \mathrm{mmol}, 1.2$ equiv), $\mathrm{Ru}\left[\left(p \text {-cymene) } \mathrm{Cl}_{2}\right]_{2}\right.$ (4 mg, $0.0069 \mathrm{mmol}, 10 \mathrm{~mol} \%)$, TFAA $(0.18 \mathrm{~mL})$, and TFA $(0.004 \mathrm{~mL})$. The tube was then sealed and heated to $80^{\circ} \mathrm{C}$ for $18 \mathrm{~h}$. After cooling, the reaction mixture was added to sat. aq $\mathrm{NaHCO}_{3}(10 \mathrm{~mL})$ and then extracted with EtOAc $(3 \times 15 \mathrm{~mL})$. The combined organic layers were washed with $\mathrm{H}_{2} \mathrm{O}(10 \mathrm{~mL})$ and brine $(10 \mathrm{~mL})$, then dried $\left(\mathrm{MgSO}_{4}\right)$, filtered, and concentrated in vacuo. The crude product was purified by column chromatography (silica gel, 5\% EtOAc-hexane) to give a pale-yellow solid; yield: $12 \mathrm{mg}$ (38\%); $R_{f}=0.86$ (20\% EtOAc-hexane); $\mathrm{mp} 98-99^{\circ} \mathrm{C}$. FTIR (solid): 3080 (O-H), 2918 (C-H), 2849 (C-H), 1652 (C=O), 1484 $(\mathrm{C}=\mathrm{C}), 1277(\mathrm{C}-\mathrm{O}), 1207(\mathrm{C}-\mathrm{O}) \mathrm{cm}^{-1}$.

${ }^{1} \mathrm{H} \mathrm{NMR}\left(400 \mathrm{MHz}, \mathrm{CDCl}_{3}\right): \delta=12.57(\mathrm{~s}, 1 \mathrm{H}, \mathrm{OH}), 7.62(\mathrm{~d}, J=2.9,1 \mathrm{H}$, ArH-5'), 7.40 (d, $J=9.1,1 \mathrm{H}$, ArH-3'), 7.33 (dd, $J=9.1,2.9,1 \mathrm{H}, \mathrm{ArH}-4^{\prime}$ ), $6.76\left(\mathrm{~s}, 1 \mathrm{H}, \mathrm{ArH}-2^{\prime}\right), 6.64\left(\mathrm{~s}, 1 \mathrm{H}, \mathrm{ArH}-1^{\prime}\right), 3.92(\mathrm{~s}, 3 \mathrm{H}, \mathrm{OMe}), 2.66(\mathrm{t}, J=$ 7.7, $2 \mathrm{H}), 1.66$ (p, $J=7.4 \mathrm{~Hz}, 2 \mathrm{H}), 1.26(\mathrm{~s}, 24 \mathrm{H}), 0.88$ (t, $J=6.7,3 \mathrm{H}$, $\mathrm{Me})$.

${ }^{13} \mathrm{C}$ NMR (101 MHz, $\left.\mathrm{CDCl}_{3}\right): \delta=181.6(\mathrm{C}=0), 161.5(\mathrm{C}-\mathrm{OH}), 156.3$, 156.0, 153.7, 151.0, 125.4, 120.9, 119.2, 110.3, 106.9, 106.8, 105.1, 55.9 (OMe), 36.8, 31.9, 30.6, 29.7, 29.7, 29.5, 29.5, 29.4, 29.2, 22.7, 14.1.

HRMS (ESI?): $m / z(\%)=453.2978(100)[\mathrm{M}+\mathrm{H}]^{+}, 454.3009$ (30), $455.3047(5)$

HRMS (ESI?): $m / z$ [M $+\mathrm{H}]^{+}$calcd for $\mathrm{C}_{29} \mathrm{H}_{41} \mathrm{O}_{4}:$ 453.3005; found: 453.2978 .

\section{1-Hydroxy-4-methoxy-6-pentadecyl-9H-xanthen-9-one (23)}

A tube was charged with xanthone $\mathbf{2 0}$ ( $50 \mathrm{mg}, 0.11 \mathrm{mmol}, 1.0$ equiv), PIFA (57 mg, $0.132 \mathrm{mmol}, 1.2$ equiv), $\mathrm{Ru}\left[(p \text {-cymene }) \mathrm{Cl}_{2}\right]_{2}$ (7 $\mathrm{mg}$, $0.0114 \mathrm{mmol}, 10 \mathrm{~mol} \%)$, TFAA $(1 \mathrm{~mL})$, and TFA $(0.02 \mathrm{~mL})$. The tube was then sealed and heated to $80^{\circ} \mathrm{C}$ for $18 \mathrm{~h}$. After cooling, the mixture was added to sat. aq $\mathrm{NaHCO}_{3}(10 \mathrm{~mL})$ and extracted with EtOAc $(3 \times 20 \mathrm{~mL})$. The combined organic layers were washed with $\mathrm{H}_{2} \mathrm{O}(10$ $\mathrm{mL}$ ) and brine $(10 \mathrm{~mL})$, then dried $\left(\mathrm{MgSO}_{4}\right)$, filtered, and concentrated in vacuo. The crude product was purified by column chromatography (silica gel, 5\% EtOAc-hexane) to give a yellow solid; yield: $13 \mathrm{mg}$ (26\%); $R_{f}=0.73$ (20\% EtOAc-hexane); $\mathrm{mp} 81-83{ }^{\circ} \mathrm{C}$.

FTIR (solid): = $2919(\mathrm{C}-\mathrm{H}), 2852(\mathrm{C}-\mathrm{H}), 1625(\mathrm{C}=\mathrm{O}), 1511(\mathrm{C}=\mathrm{C}), 1273$ (C-O), $1120(\mathrm{C}-\mathrm{O}) \mathrm{cm}^{-1}$.

${ }^{1} \mathrm{H}$ NMR $\left(400 \mathrm{MHz}, \mathrm{CDCl}_{3}\right): \delta=12.09(\mathrm{~s}, 1 \mathrm{H}, \mathrm{OH}), 8.11(\mathrm{~d}, J=8.1,1 \mathrm{H}$, ArH-1'), 7.34 (s, 1 H, ArH-3'), 7.21-7.14 (m, 2 H, ArH-2', $\left.4^{\prime}\right), 6.66$ (d, $J=$ 8.7, $1 \mathrm{H}$, ArH-5'), 3.90 (s, $3 \mathrm{H}, \mathrm{OMe}), 2.69(\mathrm{t}, J=7.9,2 \mathrm{H}), 1.61(\mathrm{~m}, 2 \mathrm{H})$, $1.18(\mathrm{~s}, 24 \mathrm{H}), 0.80$ ( $\mathrm{m}, 3 \mathrm{H}, \mathrm{Me})$.

${ }^{13} \mathrm{C}$ NMR $\left(101 \mathrm{MHz}, \mathrm{CDCl}_{3}\right): \delta=182.3(\mathrm{C}=0), 156.2,154.6(\mathrm{ArC}-\mathrm{OH})$, 152.4, 145.9, 140.0 (ArC-OMe), 125.7, 125.3, 120.2, 118.5, 117.3, 109.5, 108.7, 57.5 (OMe), 36.3, 31.9, 30.9, 30.7, 29.6, 29.5, 29.4, 29.4, 29.2, 22.7, 14.1.

HRMS (ESI?): $m / z(\%)=453.2995(100)[\mathrm{M}+\mathrm{H}]^{+}, 454.3034(30)$.
HRMS (ESI?): $m / z[M+H]^{+}$calcd for $\mathrm{C}_{29} \mathrm{H}_{41} \mathrm{O}_{4}: 453.3005$; found: 453.2995.

1-Hydroxy-6,7-dimethoxy-3-pentadecyl-9H-xanthen-9-one (24)

A tube was charged with xanthone $\mathbf{2 1}$ ( $45 \mathrm{mg}, 0.096 \mathrm{mmol}, 1.0$ equiv), $\mathrm{K}_{2} \mathrm{~S}_{2} \mathrm{O}_{8}$ (52 mg, $0.192 \mathrm{mmol}, 2.0$ equiv), $\mathrm{Ru}\left[(p \text {-cymene }) \mathrm{Cl}_{2}\right]_{2}$ (6 mg, $0.0096 \mathrm{mmol}, 10 \mathrm{~mol} \%)$, TFA $(1 \mathrm{~mL})$, and TFAA $(0.05 \mathrm{~mL})$. The tube was then sealed and heated to $80^{\circ} \mathrm{C}$ for $18 \mathrm{~h}$. After cooling, the mixture was added to sat. aq $\mathrm{NaHCO}_{3}(10 \mathrm{~mL})$ and extracted with EtOAc $(3 \times 10 \mathrm{~mL})$. The combined organic layers were washed with $\mathrm{H}_{2} \mathrm{O}(10$ $\mathrm{mL})$ and brine $(10 \mathrm{~mL})$, then dried $\left(\mathrm{MgSO}_{4}\right)$, filtered, and concentrated in vacuo. The crude product was purified by column chromatography (silica gel, 5\% EtOAc-hexane) to give a pale-yellow solid; yield: $20 \mathrm{mg}$ (43\%); $R_{f}=0.45$ (20\% EtOAc-hexane); $\mathrm{mp} 104-105.8{ }^{\circ} \mathrm{C}$.

FTIR (solid): 2918 (C-H), 2851 (C-H), 1645 (C=O), 1510 (C=C), 1272 (C-O), $1172(\mathrm{C}-\mathrm{O}) \mathrm{cm}^{-1}$.

${ }^{1} \mathrm{H} \mathrm{NMR}\left(400 \mathrm{MHz}, \mathrm{CDCl}_{3}\right): \delta=12.72(\mathrm{~s}, 1 \mathrm{H}, \mathrm{OH}), 7.57\left(\mathrm{~s}, 1 \mathrm{H}, \mathrm{ArH}-1^{\prime}\right)$, $6.88\left(\mathrm{~s}, 1 \mathrm{H}, \mathrm{ArH}-2^{\prime}\right), 6.73\left(\mathrm{~s}, 1 \mathrm{H}, \mathrm{ArH}-3^{\prime}\right), 6.63\left(\mathrm{~s}, 1 \mathrm{H}, \mathrm{ArH}-4^{\prime}\right), 4.02(\mathrm{~s}$, $3 \mathrm{H}, \mathrm{OMe}), 4.00(\mathrm{~s}, 3 \mathrm{H}, \mathrm{OMe}), 2.66(\mathrm{t}, J=7.7,2 \mathrm{H}), 1.66(\mathrm{p}, J=7.7,2 \mathrm{H})$, $1.25(\mathrm{~s}, 24 \mathrm{H}), 0.88(\mathrm{t}, J=6.7 \mathrm{~Hz}, 3 \mathrm{H})$.

${ }^{13} \mathrm{C}$ NMR $\left(101 \mathrm{MHz}, \mathrm{CDCl}_{3}\right): \delta=180.6(\mathrm{C}=\mathrm{O}), 161.3(\mathrm{ArC}-\mathrm{OH}), 156.2$, 155.9 (ArC-OMe), 152.9, 152.6, 146.8 (ArC-OMe), 113.5, 110.4, 106.8, 106.6, 104.5, 99.5, 56.6 (OMe), 56.4 (OMe), 36.7, 31.9, 30.7, 29.7, 29.7, 29.6, 29.5, 29.4, 29.2, 22.7, 14.1 .

HRMS (ESI?): $m / z(\%)=483.3098(100)[\mathrm{M}+\mathrm{H}]^{+}, 484.3128$ (30).

HRMS (ESI?): $m / z[\mathrm{M}+\mathrm{H}]^{+}$calcd for $\mathrm{C}_{30} \mathrm{H}_{43} \mathrm{O}_{5}: 483.3110$; found: 483.3098 .

\section{Conflict of Interest}

The authors declare no conflict of interest.

\section{Funding Information}

The authors would like to thank the South African National Research Foundation (NRF) under the German/South Africa Research Cooperation for funding of the project.

\section{Supporting Information}

Supporting information for this article is available online at https://doi.org/10.1055/s-0040-1719903.

\section{References}

(1) New address: Aliyaah Rahman, Institut für Chemie, Technische Universität Berlin, Strasse des 17. Juni 115, 10623 Berlin, Germany.

(2) Le Pogam, P.; Boustie, J. Molecules 2016, 21, 294.

(3) Masters, K.-S.; Bräse, S. Chem. Rev. 2012, 112, 3717.

(4) Roberts, J. C. Chem. Rev. 1961, 61, 591.

(5) (a) de Koning, C. B.; Giles, R. G. F.; Engelhardt, L. M.; White, A. H. J. Chem. Soc., Perkin Trans. 1 1988, 3209. (b) Kupchan, S. M.; Streelman, D. R.; Sneden, A. T. J. Nat. Prod. 1980, 43, 296.

(6) Ke, H.; Morrisey, J. M.; Qu, S.; Chantarasriwong, O.; Mather, M. W.; Theodorakis, E. A.; Vaidya, A. B. Antimicrob. Agents Chemother. 2017, 61, e01220-16. 
SynOpen

F. Jagot et al.

(7) Feng, Z.; Lu, X.; Gan, L.; Zhang, Q.; Lin, L. Molecules 2020, 25 , 598.

(8) Pailee, P.; Kuhakarn, C.; Sangsuwan, C.; Hongthong, S.; Piyachaturawat, P.; Suksen, K.; Jariyawat, S.; Akkarawongsapat, R.; Limthongkul, J.; Napaswad, C.; Kongsaeree, P.; Prabpai, S.; Jaietch, T.; Pohmakotr, M.; Tuchinda, P.; Reutrakul, V. Phytochemistry 2018, 147, 68.

(9) (a) Sousa, M. E.; Pinto, M. M. M. Curr. Med. Chem. 2005, 12, 2447. (b) Winter, D. K.; Sloman, D. L.; Porco, J. A. Jr. Nat. Prod. Rep. 2013, 30, 382.

(10) Johnson, M. M.; Naidoo, J. M.; Fernandes, M. A.; Mmutlane, E. M.; van Otterlo, W. A. L.; de Koning, C. B. J. Org. Chem. 2010, 75, 8701; corrigendum: J. Org. Chem. 2019, 84, 472.

(11) Dam, J.; Bode, M. L.; de Koning, C. B. J. Org. Chem. 2019, 84, 150.

(12) Ngwira, K. J.; Kühlborn, J.; Mgani, Q. A.; de Koning, C. B.; Opatz, T. Eur. J. Org. Chem. 2019, 4778.

(13) Other related oxidative cyclization reactions have been reported; for an example of a phenol-mediated oxidative cyclization with $\mathrm{Ag}_{2} \mathrm{CO}_{3}$, see: (a) Fuse, S.; Matsumura, K.; Johmoto, K.; Uekusa, H.; Tanaka, H.; Hirose, T.; Sunazuka, T.;
Õmura, S.; Takahashi, T. Chem. Eur.J. 2016, 22, 18450. For a DDQ oxidation of 1,4-hydroquinones to afford spiro-type compounds, see ref. 5a and: (b) Lewis, J. R.; Paul, J. G. J. Chem. Soc., Perkin Trans. 1 1981, 770.

(14) Eaton, P. E.; Carlson, G. R.; Lee, J. T. J. Org. Chem. 1973, 38, 4071.

(15) (a) Shan, G.; Han, X.; Lin, Y.; Yu, S.; Rao, Y. Org. Biomol. Chem. 2013, 11, 2318. (b) Thirunavukkarasu, V. S.; Ackermann, L. Org. Lett. 2012, 14, 6206. (c) Dias, G. G.; Rogge, T.; Kuniyil, R.; Jacob, C.; Menna-Barreto, R. F. S.; da Silva, E. N. Jr.; Ackermann, L. Chem. Commun. 2018, 54, 12840.

(16) For a discussion on triazine UV absorbers that require hydrogen-bonding to efficiently transform UV radiation into thermal energy by a process called phototautomerism, see: Hüglin, D. Chimia 2016, 70, 496.

(17) Chawla, H. M.; Pant, N.; Kumar, S.; Mrig, S.; Srivastava, B.; Kumar, N.; Black, D. StC. J. Photochem. Photobiol., B 2011, 105, 25.

(18) Mulay, S. V.; Amit Bhowmik, V.; Fernandes, R. Eur. J. Org. Chem. 2019, 4931. 